\title{
VAR model Analysis on Japan's OFDI and Industrial Structural Upgrading
}

\author{
Liang Ren ${ }^{1}$ Bing $\mathrm{Li}^{2}$ \\ ${ }^{1}$ School of Econ's and Management, Shenyang Ligong University, Shenyang, P. R. China \\ Email:Renliang79@163.com \\ ${ }^{2}$ School of Inter'1 Trade, Shandong Economic University, Jinan, P. R. China \\ Email: libingchina@sina.com
}

\begin{abstract}
This paper employs the VAR model to analyze Japan's outward foreign direct investment and its domestic industrial structural upgrading. Vector Error Correction estimates shows that there is a long term relationship between Japan's outward FDI and its industrial structural upgrading, and there is a correction mechanism functioning well in the process. The impulse response analysis results show that the shocks of the Japan's outward FDI will lead to positive effects on the first industry, and positive effects then negative to the second industry, negative then positive effects to the tertiary industry.
\end{abstract}

Keywords: VAR model, OFDI, industrial structural upgrading

\section{Introduction}

Japan has a long history in the overseas investment, but the World War II destroyed it completely. After the reconstruction and recovery that lasted for decades, Japan finally resumed its economic power at home. In the 1980's, Japan restarted its overseas investment due to the trade frictions with the United States in the auto industry. Through direct investment in the United States, Japan automakers such as Toyota, Honda etc successfully avoided trade disputes with the
Americans and increased the auto sales in the United States much faster than the export could do. Not only invested in the developed countries, Japan also established its investment in the developing Southeast Asia countries such as Philippines and Malaysia. Japanese successful overseas investment upgraded home economy to services industry and aroused many research interests. Thus, there should be some positive role in the development of foreign direct investment (FDI) especially the outward FDI (OFDI) and industrial structure upgrading.

\section{Literature Review}

Mundell (1957) $)^{[1]}$ first mathematically modeled cross-border capital flows in a Heckscher-Ohlin framework. J. H. Dunning (1977) ${ }^{[2]}$ put forward an eclectic paradigm in summarizing the FDI advantages: Ownership, Location and Internalization (OLI). Later, he continued to update and modify the theory and made it a standard explanation for the FDI.( J.H. Dunning, 1955,1998). ${ }^{[3][4]}$

However, those theories haven't associated FDI with the industrial structural upgrading. Raymond Vernon (1966) ${ }^{[5]}$ stated that there are four stages: introduction, growth, maturity and decline in the product life cycle. This theory started to link the two together by indicating that the industry structure could change because of the different stages of the prod- 
uct life cycle and the investment abroad accordingly.

Japanese economist Kojima (1973) ${ }^{[6]}$ is the first scholar who put forward the "Marginal industry" investment theory, that is, the matured and will-be recessionary industry at home country should be invested abroad by building factories and managing the businesses directly in the host country. This kind of Outward FDI will leave necessary space in the home country for new industry to grow and to promote the industrial upgrading. From this aspect, OFDI shall have the good impact upon the industrial restructuring of home country.

British scholar Cantwell (1994) ${ }^{[7]}$ and Tolentino (1993) ${ }^{[8]}$ raised an industrial upgrading technological innovation theory for the OFDI of the developing countries. They believed that developing countries' improved technical capacity of enterprises are greatly related to their OFDI growth, and home countries' domestic industrial structuring and technological innovation capacity will have a great impact upon OFDI. Many Empirical studies on the OFDI were also carried out such as Kazuo Ogawa and Chung H.Lee $(1995)^{[9]}$, Blomstrom, M, Konan, D. \& R.Lipsey (2000) ${ }^{[10]}$ and Salvador Barrios , Holger Gorg \& Eric Strob $(2005)^{[11]}$.etc.

Chinese scholars have also done many research works upon this field. Wang Qi (2004) ${ }^{[12]}$ commented on the path and transmission mechanism of OFDI upon home country's industrial restructuring. He thought that Outward FDI is a practical way for China's industrial upgrading and that the appropriate choice of industry can effectively enhance China's FDI outflow scale. Recent studies include Guo Zhiyi,Cheng Gang, (2009) ${ }^{[13]}$. However, some other scholars Fan Huanhuan, Wang Xiangning (2006) ${ }^{[14]}$ drew a conclusion that OFDI couldn't upgrade its industrial structure actually according to their research by employing autoregressive distributed lag model (ADL).

Therefore, it is necessary to further study the relationship of OFDI and industrial structural upgrading, to explore whether OFDI could promote domestic industrial optimization or not and the effectiveness of OFDI upon country's industrial restructuring. This paper will use Var model and vector error correction model to do the empirical test on the data of Japan.

\section{Empirical Analysis}

\subsection{Model and Data}

The VAR model is mainly used for the relevant time series prediction system and the dynamic impact of random disturbance on variables system. If $\mathrm{Xt}$ is a $\mathrm{k}$ dimensional vector of endogenous variables, the mathematical expression of $\operatorname{VAR}(\mathrm{p})$ model in general is:

$$
X_{t}=\alpha+\beta_{1} X_{t-1}+\beta_{2} X_{t-2}+\cdots+\beta_{p} X_{t-p}+\mu_{t}
$$

If there is no unit root among variables, estimate could be done directly on the model (1), otherwise cointegration test should be carried out with variables. If the cointegration relations do not exist, the one-order difference model should be adopted to estimate parameters:

$$
\Delta X_{t}=\beta_{1} \Delta X_{t-1}+\beta_{2} \Delta X_{t-2}+\cdots+\beta_{p} \Delta X_{t-p}+\Delta \mu_{t}
$$

If the variable cointegration relationship exists, the following error correction model could be used for parameter estimation:

$$
\Delta X_{t}=\alpha+\beta_{1} \Delta X_{t-1}+\beta_{2} \Delta X_{t-2}+\cdots+\beta_{p} \Delta X_{t-p}-A \Gamma X_{t-1}+\mu_{t}
$$

Of which, $\mathrm{P}$ is the variable lag order, $\mathrm{r}$ in the $\Gamma\left(\mathrm{r}^{*} \mathrm{k}\right)$ matrix is the number of 
cointegration vectors, $\mathrm{A}(\mathrm{k} * \mathrm{r})$ is the coefficient matrix.

In this paper, data are adopted from "UNCTAD Statistical Yearbook". Sample period is selected during the years of 1981-2008.Model Variables include Japan's Outward FDI (OFDI) and the proportion of primary industry, secondary and tertiary industries in the GDP and recorded as $\mathrm{JC} 1, \mathrm{JC} 2$ and $\mathrm{JC} 3$. The data of Japan's OFDI stock instead of flow shall be used in the test because the stock actually could play a much more important role in the long-term industrial upgrading than flow data can do. The variables are transformed using natural $\log$ function and recorded as LNJOFDI, LNJC1, LNJC2, LNJC3 respectively. The Eviews 5.0 is used as the software for analysis.

\subsection{ADF and Granger Causality Test}

The Augmented Dickey and Fuller (ADF) test method is used for each variable unit root test. Test results as shown in Table 1 indicate that the $\mathrm{ADF}$ values of all the four series of LNJC1, LNJC2, LNJC3 and LNJOFDI are bigger than the critical value at a certain significant level, showing that there are root units and they are not stationary. But the ADF test values of all the first order differential variable sequences DLNJC1, DLNJC2, DLNJC3 and DLNJOFDI are smaller than the corresponding critical value at a certain significant level, showing that there are no unit roots and they are stationary. Thus, we can be sure that variables under test are the first-order difference stationary series I(1), so that Granger test can be carried out.

\begin{tabular}{c|l|l|l|l|l}
\hline Variables & Selection $(\mathrm{c}, \mathrm{t}, \mathrm{p})$ & ADF value & Probability & Critical Value & Result \\
\hline LNJC1 & $(\mathrm{c}, 0,3)$ & -2.545571 & 0.1179 & $-2.635542^{*}$ & Non-stationary \\
\hline LNJC2 & $(\mathrm{c}, 0,1)$ & -0.663842 & 0.8390 & $-2.629906^{*}$ & Non-stationary \\
\hline LNJC3 & $(\mathrm{c}, 0,1)$ & -0.816528 & 0.7976 & $-2.629906^{*}$ & Non-stationary \\
\hline LNJOFDI & $(\mathrm{c}, 0,1)$ & -1.264659 & 0.6301 & $-2.629906^{*}$ & Non-stationary \\
\hline DLNJC1 & $(\mathrm{c}, 0,0)$ & -6.105232 & 0.0000 & $-3.711457^{* * *}$ & Stationary \\
\hline DLNJC2 & $(\mathrm{c}, 0,0)$ & -2.771022 & 0.0763 & $-2.629906^{*}$ & Stationary \\
\hline DLNJC3 & $(\mathrm{c}, 0,0)$ & -2.751366 & 0.0793 & $-2.629906^{*}$ & Stationary \\
\hline DLNJOFDI & $(\mathrm{c}, 0,0)$ & -6.416253 & 0.0000 & $-3.724070^{* *}$ & Stationary \\
\hline
\end{tabular}

Note: Among Selection(c, t, p), c means constant, t means trends, $\mathrm{p}$ means difference lagging order; $\mathrm{D}$ indicates difference; $*, * *, * * *$ represent the Mackinnon critical value at $10 \%, 5 \%, 1 \%$ significant level respectively.

Table 1: ADF Test Results for Each Variable.

\begin{tabular}{l|l|l|l}
\hline Null Hypothesis & F Statistics & Probability & Conclusion \\
\hline LNJC1does not Granger Cause LNJOFDI & 7.24319 & 0.00187 & Accept \\
LNJOFDI does not Granger Cause LNJC1 & 1.35422 & 0.29608 & Accept \\
\hline LNJC2 does not Granger Cause LNJOFDI & 1.60448 & 0.22459 & Accept \\
LNJOFDI does not Granger Cause LNJC2 & 3.78582 & 0.02541 & Reject \\
\hline LNJC3 does not Granger Cause LNJOFDI & 1.54304 & 0.24030 & Accept \\
LNJOFDI does not Granger Cause LNJC3 & 4.60128 & 0.01266 & Reject \\
\hline
\end{tabular}

Note: Observation period 24, Lagging order 4.

Table 2: The results of pair-wise Granger causality tests for variables. 
The Granger test results as shown in Table 2, at lagging order of 4 and $10 \%$ significant level, indicate that LNJC1 Granger causes LNJOFDI, but LNJOFDI doesn't Granger cause LNJC1, which means a one-way Granger cause of LNJC1 and LNJOFDI. The results also show that neither LNJC2 nor LNJC3 Granger causes LNJOFDI, but LNJOFDI does Granger Cause both LNJC2 and LNJC3. This means there is only one-way Granger cause of LNJOFDI to LNJC2 and to LNJC3. This shows that Japan's OFDI stock does help explain the changes of the proportion of Japan's second industry and the tertiary industry, but couldn't help explain the changes of the proportion of the first industry, on the contrary, the changes of proportion of the first industry help explain Japan's outward investment.

\subsection{Cointegration and VEC Model}

The cointegration method, based on the VAR model proposed by Johansen (1988, 1991) and Johansen and Juselius (1990), is carried out to test the possible longterm stable relationship that may exist in variables. Cointegration test results, as shown in table 3 , indicate that there is one and only one cointegration equation existing between LNJC1 and LNJOFDI and that there is one and only one cointegration equation existing between LNJC2 and LNJOFDI, between LNJC3 and LNJOFDI respectively, too. The cointegration vector of LNC1 and LNJOFDI is $(1,0.312550)$, and that of LNJC2 and LNJOFDI is $(1,0.113215)$, for the LNJC3 and LNJOFDI is $(1,-0.061165)$.

Vector Error Correction estimates can be done accordingly between LNJC1 and LNJOFDI, between LNJC2 and LNJOFDI, between LNJC3 and LNJOFDI respectively as shown in Table 4 . The estimates in Table 4 indicate that the coefficient of Cointegration Equation 1 between LNJC1 and LNJOFDI is -
$0.235090<0$, showing that the short term correction will be conducted with a $23.5 \%$ speed within 1 year period while there are any diversions away from the long term route. Table 4 also indicates that the coefficient of Cointegration Equation 2 between LNJC2 and LNJOFDI is $-0.137185<0$, showing that while there is any diversions away from the long term route, the short term correction will be conducted with a $13.7 \%$ speed within 1 year period. For the Cointegration Equation 3, the coefficient between LNJC3 and LNJOFDI is $-0.173208<0$, showing that the correction speed will be $17.3 \%$. For comparison, the correction speed for the LNC1 and LNJOFDI is biggest, for the LNJC3 and LNJOFDI is second, and that for LNJC2 and LNJOFDI is the slowest.

\subsection{Impulse Response Function}

The impulse response function (IRF) based on cointegration model analysis will measure the impact on current and future value of endogenous variables from a standard innovation shock of random perturbation. The IRF analysis results are shown as in Figure 1, 2 and 3. Figure 1 is the response of LNJC1 to Cholesky one Standard Deviation (S.D.) LNJOFDI innovation. The results show that shocks from LNJOFDI will lead to positive response of LNJC1 at the beginning, but the intensity of the impacts will go down gradually. Figure 2 shows that the response of LNJC2 to Cholesky one S.D. LNJOFDI innovation is positive before period 7 and becomes negative after that. The positive effects reach to the maximum point of at period 4 . Figure 3 shows that the response of LNJC3 to Cholesky one S.D. LNJOFDI innovation is negative at first, and then turns to positive after period of 6 . The lowest point is at period of 4 . 
The 2010 International Conference on E-Business Intelligence

\begin{tabular}{|c|c|c|c|c|c|}
\hline Variables & Hypo No. of CE(s) & Eigenvalue & Trace Statistics & $5 \%$ Critical Value & Prob** \\
\hline \multirow{3}{*}{$\begin{array}{l}\text { LNJC1 } \\
\text { and } \\
\text { LNJOFDI }\end{array}$} & None* & 0.475535 & 19.52442 & 15.41 & 0.0117 \\
\hline & At most 1 & 0.126808 & 3.389992 & 3.76 & 0.0656 \\
\hline & \multicolumn{5}{|c|}{$\begin{array}{l}\text { Trace test indicates } 1 \text { cointegrating equation(s) at the } 5 \% \text { level. Cointegrating Vec- } \\
\text { tor }(1,0.312550) \text {, standard error }(0.02628) . * \text { denotes rejection of the hypothesis at } \\
\text { the } 5 \% \text { level }\end{array}$} \\
\hline \multirow{3}{*}{$\begin{array}{l}\text { LNJC2 } \\
\text { and } \\
\text { LNJOFDI }\end{array}$} & None* & 0.452769 & 17.06313 & 15.41 & 0.0288 \\
\hline & At most 1 & 0.076551 & 1.991005 & 3.76 & 0.1582 \\
\hline & \multicolumn{5}{|c|}{$\begin{array}{l}\text { Trace test indicates } 1 \text { cointegrating equation(s) at the } 5 \% \text { level. Cointegrating vector } \\
(1,0.113215) \text {, standard error }(0.02266) . * \text { denotes rejection of the hypothesis at the } \\
5 \% \text { level }\end{array}$} \\
\hline \multirow{3}{*}{$\begin{array}{l}\text { LNJC3 } \\
\text { and } \\
\text { LNJOFDI }\end{array}$} & None* & 0.523072 & 22.04593 & 15.41 & 0.0045 \\
\hline & At most 1 & 0.131900 & 3.536213 & 3.76 & 0.0600 \\
\hline & \multicolumn{5}{|c|}{$\begin{array}{l}\text { Trace test indicates } 1 \text { cointegrating equation(s) at the } 5 \% \text { levels. Cointegration vec- } \\
\text { tor }(1,-0.061165) \text {, standard error }(0.0098) . * \text { denotes rejection of the hypothesis at } \\
\text { the } 5 \% \text { level }\end{array}$} \\
\hline
\end{tabular}

**MacKinnon-Haug-Michelis (1999) p-values

Table 3: VAR Model Variables Cointegration Test.

\begin{tabular}{|c|c|c|c|c|c|}
\hline $\begin{array}{l}\text { Cointegrating } \\
\text { Eq1 between } \\
\text { LNJC1 and } \\
\text { LNJOFDI }\end{array}$ & CointEq1 & $\begin{array}{l}\text { Cointegrating } \\
\text { Eq2 between } \\
\text { LNJC2 and } \\
\text { LNJOFDI }\end{array}$ & CointEq2 & $\begin{array}{l}\text { Cointegrating } \\
\text { Eq3 between } \\
\text { LNJC3 and } \\
\text { LNJOFDI }\end{array}$ & CointEq 3 \\
\hline LNJC1(-1) & 1.000000 & LNJC2(-1) & 1.000000 & LNJC3(-1) & 1.000000 \\
\hline LNJOFDI(-1) & $\begin{array}{l}0.312550 \\
(0.02628) \\
{[11.8923]}\end{array}$ & LNJOFDI(-1) & $\begin{array}{l}0.113215 \\
(0.02266) \\
{[4.99719]}\end{array}$ & LNJOFDI(-1) & $\begin{array}{l}-0.061165 \\
(0.00982) \\
{[-6.22548]}\end{array}$ \\
\hline $\mathrm{C} 1$ & -4.523477 & $\mathrm{C} 2$ & -4.889972 & $\mathrm{C} 3$ & -3.414647 \\
\hline $\begin{array}{l}\text { Error Correc- } \\
\text { tion: }\end{array}$ & $\mathrm{D}(\mathrm{LNJC1})$ & $\begin{array}{l}\text { Error Correc- } \\
\text { tion: }\end{array}$ & $\mathrm{D}(\mathrm{LNJC} 2)$ & $\begin{array}{l}\text { Error Correc- } \\
\text { tion: }\end{array}$ & $\mathrm{D}$ (LNJC3) \\
\hline CointEq1 & $\begin{array}{l}-0.235090 \\
(0.09309) \\
{[-2.52533]}\end{array}$ & CointEq 2 & $\begin{array}{l}-0.137185 \\
(0.03726) \\
{[-3.68157]}\end{array}$ & CointEq3 & $\begin{array}{l}-0.173208 \\
(0.03842) \\
{[-4.50884]}\end{array}$ \\
\hline $\mathrm{D}(\mathrm{LNJC1}(-1))$ & $\begin{array}{l}-0.276681 \\
(0.20937) \\
{[-1.32147]}\end{array}$ & $\mathrm{D}($ LNJC2(-1)) & $\begin{array}{l}0.428814 \\
(0.18682) \\
{[2.29534]}\end{array}$ & $\mathrm{D}(\mathrm{LNJC} 3(-1))$ & $\begin{array}{l}0.447471 \\
(0.17465) \\
{[2.56206]}\end{array}$ \\
\hline $\mathrm{D}(\mathrm{LNJC1}(-2))$ & $\begin{array}{l}-0.189796 \\
(0.24627) \\
{[-0.77069]}\end{array}$ & $\mathrm{D}(\operatorname{LNJC} 2(-2))$ & $\begin{array}{l}-0.453239 \\
(0.18902) \\
{[-2.39785]}\end{array}$ & $\overline{\mathrm{D}(\mathrm{LNJC} 3(-2))}$ & $\begin{array}{l}-0.443321 \\
(0.16840) \\
{[-2.63249]}\end{array}$ \\
\hline $\begin{array}{l}\text { D(LNJOFDI(- } \\
1) \text { ) }\end{array}$ & $\begin{array}{l}-0.099586 \\
(0.09070) \\
{[-1.09798]}\end{array}$ & $\begin{array}{l}\text { D(LNJOFDI(- } \\
1))\end{array}$ & $\begin{array}{l}0.011410 \\
(0.03042) \\
{[0.37504]}\end{array}$ & $\begin{array}{l}\text { D(LNJOFDI(- } \\
1))\end{array}$ & $\begin{array}{l}-0.004783 \\
(0.01537) \\
{[-0.31129]}\end{array}$ \\
\hline $\begin{array}{l}\text { D(LNJOFDI(- } \\
2) \text { ) }\end{array}$ & $\begin{array}{l}0.153114 \\
(0.09874) \\
{[1.55062]}\end{array}$ & $\begin{array}{l}\text { D(LNJOFDI(- } \\
2))\end{array}$ & $\begin{array}{l}0.090237 \\
(0.03084) \\
{[2.92604]}\end{array}$ & $\begin{array}{l}\text { D(LNJOFDI(- } \\
2) \text { ) }\end{array}$ & $\begin{array}{l}-0.056111 \\
(0.01650) \\
{[-3.40160]}\end{array}$ \\
\hline
\end{tabular}

Note: Included observations:25 after adjustments , Standard errors in ( ) \& t-statistics in [ ]

Table 4: Vector Error Correction Estimates. 
Those results mean that the shocks of the Japan's outward FDI will lead to positive effects on the first industry but the influence will be gradually decreasing. The shocks of Outward FDI of Japan will lead to positive effects to the second industry then it turns negative to the second industry. But the shocks of the Japan's outward FDI will be negative at the beginning, and then it turns positive to the tertiary industry.

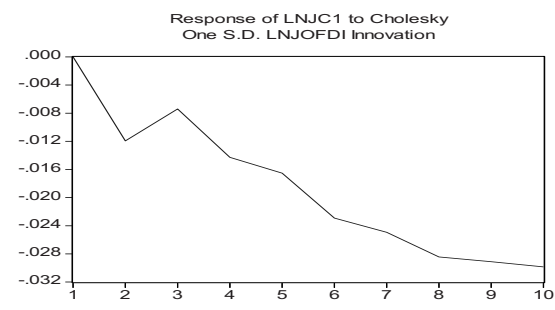

Fig.1: IRF analysis of LNJC1.

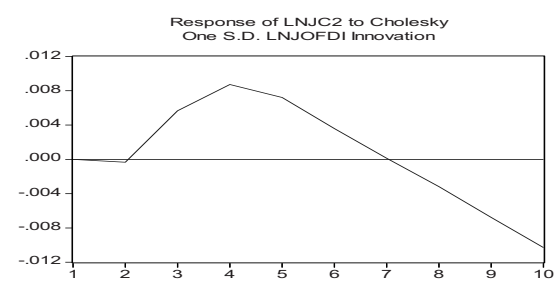

Fig. 2: IRF analysis of LNJC2.

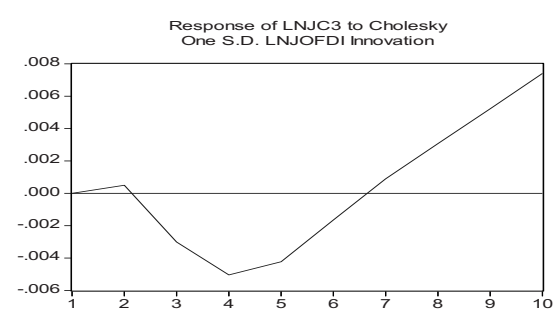

Fig.3: IRF analysis of LNJC3.

\section{Conclusion}

(1) The Granger test results indicate that LNJC1 Granger causes LNJOFDI, but LNJOFDI doesn't Granger cause LNJC1, which means a one-way Granger cause of LNJC1 and LNJOFDI. The results also show that neither LNJC2 nor LNJC3 Granger causes LNJOFDI, but LNJOFDI does Granger Cause both LNJC2 and LNJC4. This means there is only one-way Granger cause of LNJOFDI to LNJC2 and to LNJC3. This shows that Japan's OFDI stock does help explain the changes of the proportion of Japan's second industry and the tertiary industry, but couldn't help explain the changes of the proportion of the first industry, on the contrary, the changes of proportion of the first industry help explain Japan's outward investment.

(2) The cointegration test results indicate that there is one and only one cointegration equation existing between LNJC1 and LNJOFDI, between LNJC2 and LNJOFDI, between LNJC3 and LNJOF$\mathrm{DI}$ respectively. The long term cointegration vector of LNJC1 and LNJOFDI is (1, $0.312550)$, and that of LNJC2 and LNJOFDI is $(1,0.113215)$, for the LNJC3 and LNJOFDI is $(1,-0.061165)$. Vector Error Correction estimates indicates that the short term correction will be conducted with a speed of $23.5 \%, 13.7 \%$ and $17.3 \%$ to draw back the long term diversion of the cointegration equation between LNJC1 and LNJOFDI, between LNJC2 and LNJOFDI, between LNJC3 and LNJOFDI respectively. This shows that there is a long term relationship between Japan's outward FDI and its industrial structural upgrading, and there is a correction mechanism functioning well in the process.

(3) The impulse response analysis results show that the shocks of the Japan's outward FDI will lead to positive effects on the first industry but the influence will be gradually decreasing. The shocks of Outward FDI of Japan will lead to positive effects to the second industry then it turns negative to the second industry. But the shocks of the Japan's outward FDI will be negative at the beginning, and 
then it turns positive to the tertiary industry.

(4) From the analysis of Japan's outward FDI and industry structural upgrading, we can see that Japan's experience is useful in the China's industrial structural upgrading. Because China is faced with many similar problems like Japan in its development process such as trade frictions, energy constraints, and environmental pollutions. Japan has solved much of those problems through outward direct investment and its success is good for China's references.

\section{Acknowledgement}

This paper is funded by Shandong $\mathrm{Na}$ tional Science Fund (Shandong FDI Trade Effects and Policy Implications, Y2007H24) and Ministry of Education Humanity and Social Sciences Project (Theory and Empirical Tests on FDI and Trade Structure Restructuring, 09YJC790174).

\section{References}

[1] Mundell, Robert A., "International Trade and Factor Mobility," American Economi. Review, June 1957, pp 321-335.

[2] Dunning, J. H. "Trade, location of economic activity and the MNE: A search for an eclectic approach" In B. Ohlin, P. Hesselborn \& P M. Wijkman, editors, The international allocation of economic activity: Proceedings of a Nobel symposium. Macmillan, London, 1977,pp. 395-418.

[3] Dunning, J. H.. "Reappraising the eclectic paradigm in an age of alliance capitalism". Journal of International Business Studies, vol. 26(3), 1995, pp. 461-491.

[4] Dunning, J. H.. "Location and multinational enterprise: A neglected fac-
tor",Journal of International Business Studies, vol 29(1), 1998, pp.45-66.

[5] Raymond Vernon. "International investment and international trade in the product cycle". Quarterly Journal of Economics 80, 1966, pp. 190-207.

[6] Kojima, K, "A Macroeconomic Approach to Foreign Direct Investment". Hitotsubashi Journal of Economics, 14(1),1973, pp $1-21$.

[7] Cantwell, J,"Foreign Direct Investment in Developing Countries: The case of Latin America". The Methodological Problems Raised by the Collection of FDI Data//En IRELA. 1994, pp 9-27.

[8] Tolentino, P E.,"Technological Innovation and Third World Multinationals". London and New York: Routledge Press, 1993, pp 101-104.

[9] Kazuo Ogawa. \& Lee, Chung, "Returns on Capital and Outward Direct Foreign Investment: The Case of Six Japanese Industries".Journal of Asian Economics, 6:4, 1995, pp. 437-467.

[10]Blomstrom, M. Konan, D. \& R.Lipsey, "FDI in the Restructuring of the Japanese Economy", 2000 NBER Working Paper 7693.

[11]Salvador Barrios Holger Gorg Eric Strob, "FDI, Competition and Industrial Development in the Host Country", European Economic Review Volume 49 number 5 2005, pp 516-547.

[12]Wang Qi. "The Effects and Transmission Mechanism of OFDI upon Home Country' Industrial Restructuring". Forum of World Politics and Economics, (1): 2004, pp 17-21 (In Chinese).

[13] Guo ZhiYi, Cheng Gang, "Chinese Enterprises Overseas Investment Strategy based on National Interests", Journal of Innovation, (4) 2009, pp: 83-96 (In Chinese).

[14]Fan Huanhuan, Wang Xiangning. "The Impacts of China's OFDI upon Domestic Industry Structure", Technology Management Research. (11): 2006, pp: 56-58 (In Chinese). 